\title{
The Trail of Tears Poems Revisited
}

\author{
Dr. Adil M. Jamil
}

Associate Professor of English, Faculty of Arts and Sciences, Amman Arab University, Amman, Jordan

\begin{abstract}
This study examines the Native Americans' discourse as revealed in some poems under the title Trail of Tears written by Native American poets and non-Native Americans sympathetic to the cause of indigenous people. A careful examination of such verses showcases that the discourse is always fashioned to yield four distinctive themes: (a) resentment at the atrocities of the settlers and their devastating impact on the Natives; (b) the tragic events as an emblem of ongoing injustice and an inspiration for all American Natives to remember, learn, and protect their identity and resist aggression; (c) genuine faith in the immortality of the soul and the spirituality of the natural world where divine spirits roam and supply moral support and empowerment to oppressed souls; (d) perseverance to protect identity and to keep struggling against aggression until justice is served. Whether the poem is written by an anthologized adept poet or a novice writer, these components are brilliantly articulated to serve the overall purpose of the Natives' cause - i.e., to win the support of the world body of justice and to impel fellow Natives to continue resisting the aggression.
\end{abstract}

Keywords-Native Americans, Trail of Tears, Removal Act, Poetry of Indigenous People, Spirituality of Nature.

\section{INTRODUCTION}

\section{Limitations of Study}

This study is limited to the examination of the Natives' discourse as revealed in nine representative poems exclusively dedicated to the Trail of Tears, carrying partly or entirely the same title and written by Native poets and sympathizers. The study moves chronologically from the earliest published poems to the most recent ones in an attempt to highlight the common ground, the poetic techniques and above all the growing sense of empowerment and dedication the poets display in the verses.

\section{The Trail of Tears in Brief}

All concerned historians consider the events Trail of Tears, or the e relocation of Indians in 1838, as the beginning of Native Americans' catastrophe and holocaust (Stannard, 1993; Thornton, 1987). Decades before and even after the American Independence, the Native tribes lived peacefully in the Eastern states, integrating and trading with the newly developing white communities and enjoying self-rule governments, while helping the US troops whenever called upon. The Cherokee fought by the side of Andrew Jackson when he was commander of the Tennessee Militias. They helped Jackson to win the Battle of Horseshoe Bend against the Creek Indians, forcing them to surrender vast lands in Alabama and Georgia in 1813. Also with the help of the Cherokee, Choctaw, and some Creeks, Jackson put down the rebellion of the Seminole Red Sticks, the allies of Britain and
Spain. But things changed drastically during the Era of Common Man, especially after the election of Andrew Jackson as president of the United States (Burnett, 1890; Wallace 2011; Morris, 2007).

Despite the old comradeship and cahoots, after his election in 1829 Jackson strove desperately to convince Congress to approve his notorious bill of the Indian Removal Act in 1830. Afterwards, he and followers openly led a systematic campaign to demonize the used-to-be civilized tribes and allies, accusing them of being heathens, anti-Christ, less intelligent, less ambitious, less principled, and, worse, unfit to have any immediate contact with white communities until they cast off their savage habits and became Christians (Stannard, 1993; Thornton, 1987). In 1838, the US government, led by President Martin Van Buren, Jackson's successor, put into effect Jackson's bill. It began forcibly relocating the East Coast Indian five tribes Cherokee, Creek, Choctaw, Seminole, and Chickasaw, to a new land across the Mississippi River in Oklahoma State. All the Natives were ordered to evacuate, except for very few who either retreated to the swamps, caves, and mountains or readily surrendered ancestral heritage and accepted humiliating assimilation (Baird, 1973; Grenke, 2005). The tragic march of about 17,000 Cherokees along with approximately 2,000 Cherokeeowned black slaves began on October 18, 1838, and only half of the total evacuees reached the final destination on March 26, 1839 . 
During the one 1,000-mile journey, the Natives endured the unendurable - cold weather, starvation, humiliation, and disease. Deliberately the military escorts routed the trail to pass through areas of known cholera epidemics (Stannard, 1993). As epidemic diseases spread among them, the escorts did not allow them to go into any town or village along the way, so the white settlers would not catch the infection. During the six-month journey several thousands died. The death toll of Indians has been variously estimated (Mooney, 2017). Some estimate 4,000 deaths (Carter, 1976). Others estimate 8,000 deaths, about half of the total population (Stannard, 1993). Ironically, the unprecedented plight and loss of innocent souls went unnoticed by the federal government (Adams, 1973; Mooney, 2005; Hill, 2011). However, the gruesome events that accompanied the Indians' march were later documented by historians and witnesses. For instance, John G. Burnett, a member of the mounted infantry who took part in the removal of Cherokees from their homeland, describes the march as "the execution of the most brutal order in the History of America. In the beginning, men working in the fields were arrested and driven to the stockade [concentration camp] ... women dragged from their homes by soldiers... children separated from parents, the old and infirm prodded with bayonets to hasten them to the stockades, leaving dead children behind without burial; and many mothers fell dead because of heart failure, shock, or fatigue" (Burnett, 1890). Another volunteer from Georgia who participated in the removal recounts, "I fought through the War Between the States and have seen many men shot, but the Cherokee Removal was the cruellest work I ever knew" (Mooney, 124). Martin Davis, a commissary agent, describes as follows the hardship the Natives endured while waiting for the ferry to cross the frozen river: "This is the coldest weather in Illinois I ever experienced anywhere. The streams are all frozen over... It snows here every two or three days at the farthest... We have only travelled 65 miles $(105 \mathrm{~km})$ on the last month, including the time spent at this place, which has been about three weeks" (Adams,1972). In addition, many testimonies make known what has been concealed-the cruelty of the evacuators and the miseries of the evacuees (Brown, 2007).

The Trail of Tears is often taken by observers as the beginning of the Native Americans' holocaust, which is unfortunately followed by a series of bloody events for a reason not hard to discern: to wipe out the Natives from their entire homeland. Yet the Indians survived the onslaught of destruction and rose out of the ashes, embracing their own identity, resisting the aggression, and continue calling for justice. To the Natives, the Trail of Tears has ever remained an emblem of injustice and a living reminder of the most brutal campaign in the History of America, as continuously revealed in the writings of the Natives and sympathizers.

\section{The Natives' Arts of Resistance}

After a series of extermination and destruction, most Indians came to the bitter conclusion that physical resistance against the US invincible force was implausible; thus, there was nothing left for them to resist the aggression and make their voice heard but through linguistic resistance - i.e. the power of language (Rader 148). Recognizing realities, the "Native Americans see language as a viable weapon to protect cultural identity and sovereignty" (Rader 148). Language to them - contestation, continuation, and resistance - is the only available medium for expression. Through language they reserve their identity, traditions, and the story of their miraculous survival of the long series of systematic genocides and massacres. The Native artists embrace the idea that the power of language lying in arts "can be used to heal, regenerate, to recreate, and to correct misinformation and stereotypes long advocated by outsiders" (Archuleta 91). In their writings, the Natives contest that attempts of forced assimilation or continued threats of violence have not achieved the goal in mind of oppressor. More than 500 years of trying to erase, ignore, or to keep the oppressed nations silent have remained futile. The Natives have ever stood defiant despite the oppression through the years. Furthermore, all forms of arts are invested to help distressed souls "become empowered rather than victimized by destruction," as Joy Harjo puts it (Harjo 21). Through language, Native writers bring to life "too painful, too stark and sharp" stories, with which they may awaken "the ignorant of truthful history," as Linda Noel proclaims (qtd. in Harjo 234). Powerful language is used to lift off the veil of the hidden truth and make it readily perceived so as to create a body of collective knowledge that may recognize the truth and possibly change.

\section{War Poems of Native Americans}

Over the past five centuries, war has become a fundamental part of the Natives' life, and thus it is always present in the arts they produce. In their war poems, the Natives delineate with vivid images "the long tales of starvation, diseases, loss of innocent people, and resistance as constant realities of...[those] still living in a war zone" (Hernandez-Avila 9). They often resort to the mode of documented narrative genre and rely mainly on the all-too-clearly-written texts of history 
(Gould,1995), which continuously make reference to tragic events, such as the infamous Trail of Tears, Sand Creek Massacre, and Wounded Knee Massacre beside other tragic events suffered by the Natives. The atrocities the Natives endured throughout the years, such as ethnic cleansing, indignation, mass destruction of nature, and extermination, are always the recurring themes in war poems. However, war miseries are not used as an occasion for weeping and wailing, but as a compelling motivation for the Natives to embrace their identity and persist in their struggle until they their unalienable rights for life, freedom, and pursuit of happiness.

\section{The Verses of Trail of Tears}

Among many other tragic events, the Trail of Tears is still lurking into the mind and conscience of Native artists, and it inhabits nearly all forms of arts they produce. From the very beginning of the 20th century up to the present, poems are still emerging commemorating the tragic events of the Indians' removal. References to the Trail of Tears can be encountered in almost every poem written by the Natives to keep reminding the world body of the need for justice for what seemingly has been forgotten or intentionally neglected by all concerned parties. To keep the memory of the holocaust alive and to expose the concealed truthful history, some poets take the Trail of Tears as a title, partly or entirely, for their poems. The selected poems delineate to some degree resemblances to the major trends often encountered in other war poems, yet they share certain features of their own. The poets, whether Native Americans or liberal writers, novice or adept, resort to the mode of documented narrative genre and make specific references to four major components: (a) the miserable events and their devastating impact on the Natives; (b) a strong faith in the spirituality of the natural world and the immortality of soul; (c) the natural world as a sphere where divine spirits roam and supply moral support and empowerment to oppressed souls; and (d) perseverance to protect identity and to keep struggling against aggression until justice is served. The selected poems are listed chronologically from the earliest to the most recent. No matter the lapse of time or the execution of poetics, the ingredients of the poems are often the same, and the common objective is readily perceived.

\subsection{Ruth Margaret Muskrat's The Trail of Tears (1922)}

Muskrat's is a typical Indian war poem, inspired by the memory of the Trail of Tears. This poem in specific sets the tone, ingredients, and premises for most poets elaborating the major catastrophe of the Natives. The devastation of the
Trail, strong faith in the spirituality of the natural world and the immortality of the soul, the natural world as a sphere of sympathetic spirits roaming and supplying moral support to oppressed souls, and the pride the Natives take in their heritage and the legitimacy of their cause are vividly exemplified in this poem. Strong faith in nature is the main focus in Section 1. Nature is introduced as the only safe haven, a sympathetic ally that soothes the tormented souls on the Trail and even after. The image of "tall pines" illustrates the sensibility of nature as opposed to the insensibility of man, who mass murders nature and fellow people. The pines still "shriek and moan, / As they guard the dismal trail" to echo the misery of forefathers "on that weary trail of tears." The sensibility of nature is further elaborated in Section 2. Nature still groans over the loss of 4,000 victims who fell on the road of tears. As does nature, the Great Spirit soothes "the souls of his people / As they travel the trail of tears." To the Natives, God and nature are closely interrelated. In nature the Great Spirit resides; thus nature is in turn imbued with divine attributes, or it can manifest as God. In Section 3, the verses appeal to resentment at the atrocities of white settlers and urge pity for her oppressed people. At the same time, Muskrat names greed as the initiator of all evils and the original sin of white settlers: "For the sake of greed and gold / The Cherokees were forced to go / to a land they did not know." Greed is the main motive and gold is the chief target; neither the idea of Manifest Destiny nor the security concern matters to the usurpers. Because of man's utter greed, "Full four thousand fell," yet no one seems to take pity on them but the Great Spirit or Nature. In nature, or the world of spirits, the Natives find a sympathetic ally conferring on them graces and endowing the power of continuity and feelings of empowerment. Despite the devastation, Muskrat's fith remains intact, and it enables her to defy the distressing circumstances. She proclaims that the injustices committed on the Trail of Tears cannot be buried or concealed: "Father Time or wisdom old / cannot erase, through endless years / The memory of the trail of tears." Harshness, dislocation, physical and spiritual displacement, and destruction have failed to erase the Natives' identity; to the contrary, she anticipates the hour of truth will inevitably come and justice will be served.

\subsection{Brian Childers's The Trail of Tears (1998)}

Brian Childers, another Native poet, delivers his own tribute to the same tragic event in his poem The Trail of Tears. The building blocks of Childers's poem are almost the same as those seen in Muskrat's; however, the tone is more sorrowful 
and grave as well less confrontational. The persona here is an Indian evacuee who treads along the road of pains with others, "stifled" by constant feelings of indignation and physical and spiritual displacement. To urge pity for the oppressed, he describes how his tears overflow in witnessing the suffering and loss of innocent souls while marching the 1,000-mile journey. Grieved and exhausted, he utters, "Mile after mile, and day after day / our people are fewer with each rising sun... Disease and starvation they take their terrible toll." The slow rhythm is meant to express the inescapable dilemma that grows more painful as they tread those prolonged miles. The sense of grief is intensified as the scene of the general tragedy narrows to a more personal arena when he watches his beloved wife "weaken and fall" like the others and "breathes her last on my arms." Devastated by his wife's death, he unconsciously looks for an outlet to rid his tormented body and soul of the accumulating pains. Soon that outlet is found-not in the world of man, but in the world of spirits or immortality. His body falls down to embrace mother nature, while his "spirit soars to greet the sky, with my dying breath am I finally set free." The oxymoron illustrated in the final line is a clear reference to the deeply rooted faith in the spirituality of the world. Death, to him, is only a continuation of man's journey to the world of immortality: It is to "begin the very long journey toward home," to where man essentially belongs, the world of spirits, where real freedom and genuine joy can be attained. He feels at home as he joins the immortal world of the Great Spirit away from the mortal world of man. Once his soul "soars" toward the place where it originally came from, a sense of wholeness and completion replaces the sense of misery engulfing his tormented soul. A feeling of empowerment or moral victory over his enemy takes over through a journey to the world of immortality.

\subsection{Del “Abe” Jones, The Never-ending Trails (2005)}

Del "Abe" Jones, a human right activist and sympathizer with the Native cause, relates the tragedy of the Trail of Tears in retrospect. In his epic ballad, he conjures up a narrative fabric that brings alive the history and memory of fear, pain, and destruction, hoping that the exposure to the truthful history may correct misinformation and stereotypes long advocated by outsiders, in turn awakening the conscience of the whites to see the truth regarding the Natives and their history. Jones's verses are inexorably connected with specific acts of aggression well documented by historians and witnesses such as Brown, Burnett, and
Stannard. Every one or two stanzas of the ballad explores a variant trauma of the Trail of Tears. Like other white sympathizers, Jones considers the Removal Act as the most brutal order in the history of America, which further led to a terrible site of cultural imperialism and eradication in the 19th century. By and large, his poetic discourse shares with other authors' the same features and concerns, the atrocities and amoral thrusts of the settlers versus the moral standards and spirituality of Indians, and the legitimacy of the Natives' cause versus the greed and fictitious claims of settlers. In the opening stanza, a feeling of shame takes over as the persona sees the white race still glorifying an axis of evil, Andrew Jackson, who is referred to as the master of the Hermitage, Jackson's compound in Tennessee. Unlike the heroic image conferred on Jackson by the common multitudes, to Jones Jackson is merely a "cruel, unjust, and unfair leader" who ordered the devilish removal "of the Cherokee from their land / And forced them on a trek." Added to this, Jones resents the idea of misusing religion to legitimize the exploitation of helpless nation, showing that Christianity is used as a cover to conceal the real motive. Jones takes greed, not religion, as the chief impulse that drove Jackson and white settlers to usurp the Indians' homeland, a premise encountered in most poems of the Natives. The Removal Act is an unforgivable crime that whites (we) should "bow our heads in shame / Even unto this day for those who died along the way." To bring his point home, the poet explores some documented details of aggression that arouse feelings of shame. The "shameful" tale begins with the inhuman raid of General Scott with 7,000 troops to "rout the Indians from" their homeland. Peaceful Indians were hunted out like wild animals while peacefully "working in the fields / Arrested, placed in a stockade" with "Women and children dragged from home." The cruelty of raiders is further illustrated in another horribly repulsive act of aggression when the troops force Indian women to leave behind a dead child without burial. They "were cruelly herded out the door-moving out with the sky as blanket and the cold earth their pillow." Further evidence of shameful acts is introduced: an image of a mother whose heart was broken while dragging her three weeping kids: "She uttered a quiet prayer- / Told the old family dog good-bye - / Then, her broken heart gave out / And she sank slowly down to die." Afterwards, Jones redirects his discourse to show the stark contrast between the moral standard and code of knighthood embraced by the Natives and the amoral code displayed by Jackson and the heartless settlers. Jackson, for example, turned down the plea of Chief Junaluska, who saved Andrew Jackson's life before 
and helped him to win the battle of Horse Shoe against the Creek "With five hundred Warriors" and "lay thirty-three Braves [Indians] to rest." Jackson coldly denied him when Chief Junaluska plead before him to stop or at least delay the Indian exodus, expecting Jackson would honor the code of knighthood: "But, Jackson was cold, indifferent ... Said, / "The Cherokee's fate is sealed-/ There's nothing, I can do." Unfortunately, white people's difference has not changed with time: "all their pleas [of Indians] and protests / To this day still go unheard."

The Indians' spirituality and moral standards are further exemplified. The thousands of victims who fell "because of freezing cold, sleet and snow" would not go to the pit of hell, the destiny of heathens as common among the white settlers, but "to join that Great Spirit in the Sky." As well, the poet retells many "humane, heroic stories" that occurred amid the tragedy to highlight the moral standards and the relatively superior ethics of the Natives. Out of nobility and benevolence, Chief Rose's wife, for example, "Gave her blanket to a sick heroic child / And in so doing, gave her life," joining the "Four thousand poor souls in all." In the concluding lines, Jones appeals once again to the whites to make amends for the "shame we try to hide," anticipating, nevertheless, that only sensible people will respond to and feel the groaning and shrieking of victimized souls along the trail of tears when listening with their "hearts," not just with their ears. Jones's words echo to a great extent Muskrat's lines: "In the night they shriek and moan, ... every shriek and echoed groan / of their forefathers that fell / with broken hopes and bitter fears / on that weary trail of tears."

\subsection{Debra Robertson's A Trail of Tears (2007)}

In Debra Robertson's poem “A Trail of Tears" the illustration of the tragic events is used as motivation for her people to recognize the astonishing endurance of their ancestors, and in turn to urge the Natives to stand steadfast in protecting their own identity and defending their sovereignty. The story of their miraculous survival of the onslaught is an inspiration and source of empowerment for the new generations to continue struggling until justice is served. Roberson powerfully insists that, "Hunger and hardship" have failed to force assimilation or to change their identity: "our journey is long, but our hearts are true" to their heritage. Strong faith in the world of immortality is also employed as a source of empowerment. In reality, the Natives were destroyed yet spiritually never defeated. Their "spirits" withstand life calamities and challenges and their "bows," the traditional symbol of resistance, "cannot be broken."
Meanwhile realities, as Robertson holds, can only be challenged by the unity of the Natives "together to be strong." In Section II, her lines grow more confrontational with the elaboration of the Natives' spiritual convictions: The spirits of the victimized ancestors "walk amongst us now / to give us strength along the way." In other words, the memory of the Trail of Tears is not an occasion for weeping, but rather a source of empowerment and continuation. With faith and perseverance, their long journey of endurance and indignation will eventually come to an end: "that long journey is at an end, our tears will no more be shed amongst us." In Section III, the poet reiterates further inspiring thoughts. She anticipates that their earnest quest for justice will eventually bear fruits and the endurance of the brave nation will be rewarded:

A new beginning, a gift from the earth spirits,

A new life is born in honor of us,

A fragrant gift to remind us all

For where there was once a trail of tears

A fragrant rose shall thus appear.

\subsection{John Trudell's poem Cry Your Tears (2008)}

John Trudell's poem Cry Your Tears is more confrontational and darkly satiric than the rest of the discussed poems. To Trudell, the tears of the Natives shed on the Trail of Tears should ever remain a living reminder of the injustices committed by white people against the Natives, not only in the Trail of Tears but also throughout the years. Trudell, empowered by the legitimacy of his cause, bitterly gloats the short memory of his oppressor, and thus rejects the idea of crying for the current wounds and injuries of white Americans: "Now you want us to cry your tears for you / After we've already bled for you, / Already been dead to you." With no qualm, he cannot imperturbably forget the old atrocities and unmindfully sympathize with the usurpers of homeland and killers of his nation. Instead, he reminds his readers that even the current so-called American democracy is essentially the consequence of long centuries of systematic genocide that led to the depopulation of his nation. His nation shrank from being the majority, to "being the smallest minority" as a result of the named massacres: "Duck Valley, Wounded Knee / Sand Creek, the Trail of Tears" and others. Trudell also resents the idea of using religious fictions by the industrial ruling class "as a weapon, distilling love into hate," annihilating an innocent nation and robbing its land, "sacrificing lives and blood / Making the innocent the new virgins / Offerings o the gods of profit, and corporate corruption." Then he takes their case to a different 
perspective. He urges the Natives to join forces with all other oppressed ethnic groups against the ruling class and "corporate corruption" and "economic terrorism." Their cause must be the cause of all unfortunate groups, the subject of the hypocrisy and double standard of government. The federal government suffocates with strict rules not only the Natives but other groups as well. The government turns a blind eye to mass murdering of people and the environment, "weaponizing the psychology of fear, breaking and faking the rules and constitution." In addition, greed is introduced as the initiator of all evil deeds in the past and present. The same old drive of the settlers is that of corrupt corporations in the present. He warns that if greed remains unchecked, things will keep deteriorating and the worst is approaching. His concluding lines bear an alarming thought directed particularly to the oppressor. If corruption prevails, it will eventually lead to a nationwide destruction, and both the oppressed and the oppressor "may end up crying together." Such a fatal consequence cannot be avoided, unless people's greed is kept in check.

\subsection{Spiritwind Wood's, And the Heavens Cried (Trail of Tears) (2009)}

In Spiritwind Wood's, And the Heavens Cried (Trail of Tears), the attachment of the Natives to the natural world is clearly illustrated first. The natural world is introduced as a living entity possessing divine attributes, imbued with passion and participating in the feelings of the tormented Natives. Over the Natives' plight, the natural world pours grief and sorrow. It "started to rain / teardrops of blood across the land, lost in their vision of doubt, buried in their pain." In Section II, the poet takes the events backward in an attempt to highlight the sharp contrast between the goodness of Natives and the cunning and deception of white man. The Natives' goodness, perhaps naiveté, is exemplified in how they peacefully watch and welcome the early arrival of settlers' "ships come in/ one by one." This peaceful attitude, however, is soon frustrated by the cunning and deception of the newcomers who hide evil intents behind "mask" and disguise - the promises they make "just lies."
The terminal refrain, repeated at the end of each section, "and the heavens cried on the trail of tears," is meant to show the cruelty of oppressor and, more importantly, to emphasize the idea that the natural world is the only sympathetic ally to the Natives. It provides moral support-it soothes their spirits and keeps them safe. The natural world, represented by the "Spirit Wind" does not only deliver moral support and sympathy but also a sense of empowerment. In the Natives' predicament, no one stands for them but the world of spirits. "The spirit wind" empowers the speaker and his nation to continue living through the "darkest years," and it enables them to stand defiant against oppression, embracing their own identity and pride: "Guided by the Spirit wind, we held our pride / something they couldn't take away." Beside their attachment to the natural world, greed is also labelled as the chief initiator of the bloody campaign carried out by an invincible might against a helpless nation. Because of greed "Blood spilled on our sacred ground / leaving an unwanted stain, and so many died / through our darkest years." Still, no matters the onslaught of destruction, the Natives, "guided by the Spirit Wind," steadfastly hold on to their pride and identity. Undoubtedly he poet stresses a major premise common among Native writers, the idea that all forms of arts must be employed to help distressed souls "to become empowered rather than victimized by destruction" (Harjo, 21).

\subsection{Mojomike8's Trails of Tears Poem (2012)}

In his Trails of Tears Poem, Mojomike8 presents his own tribute to the 1,000-mile march undertaken by men, women, and children of the Cherokee nation along with the other first American nations. His verses have the same ingredients encountered in other poems. The poem opens with a sense of loss as a consequence of the bloody campaign against the Natives. The Trail of Tears is actually a trail of blood "Flowing from our homeland / Drowning out the red man." Through fraudulent schemes, the Indian Nation was torn apart to let another nation build its shrine on the remains and corpses of the first: "A nation torn apart / So one can be born," as Trudell and others reiterate in their poems. The white American Nation rose only after the destruction and entombment of the Natives. In Section 2, the poet recalls the "freedom" and joy the Natives used to find in the natural world: "we were free / As the wind in the sky." But their joyful days come to an end when the "empty teepees [the symbol of Indian's traditional lodging] falling into dust" mark the beginning of the disproportional wars waged against them. As a consequence, the sense of loss soars as his 
people become like "an endangered species, a forgotten world pushed aside and left alone." Amidst affliction though, his faith in the world of spirits remains intact. Empowered by profound faith in his Great God whom he supplicates "to hear our prayers and our song," he never concedes nor loses hope in the coming future. With confidence, Mojomike8 vows, "But comes a time when we will rise again." Clearly the sense of loss is alleviated by strong faith, as reiterated in the other discussed poems. Remembrance of past tragic events leads to empowerment and continuity rather than negativity or resignation. The Natives trust that the Great God or Spirit will lift off their pain and enable them to tell the story of harshness, contest their enemy, and embrace tightly their own identity to defend their sovereignty, regardless of time or circumstance.

\subsection{Linda Hogan's On Our Removal, Trail of Tears (2014)}

Linda Hogan's On Our Removal, Trail of Tears is more confrontational in comparison to other poems. Like many Native writers, Hogan perceives language as a possible weapon of contestation, revolution, and continuation (Rader, 2002). In many senses, the feeling of empowerment she presses grows more intense, and the tone is more earnest and contending than what is seen in other discussed poems. Feeling empowered by her heritage and the legitimacy of her cause, she bluntly exposes the deceptive schemes the settlers resort to in usurping the Cherokee's homeland. They cunningly take advantage of the rules of primitive life and the goodness of legitimate owners. A land "with lines [boundaries] unseen" was a reality the "surveyors" took as an excuse to insidiously usurp the Indians' homeland. Since then, a struggle between a primitive world of sharing and a world of possessing erupted. It is a clash of existential proportions, as she describes, between a force that loves and worships nature and a force that exploits and mass murders nature and low and high creatures. On the one hand stand the forest, the motherland, the bonds, the mosses, the "swamplands" with "birds" and more lowly creatures, "cats and kittens, puppies and trees for shade, homing and rooting." On the other is an artificial entity made up of a cunning, thieving, bluffing, greedy, and brutal force. To highlight the difference, she asks the new heartless owners "to have compassion for" the homeland, "to love it, to thank it," insinuating the idea that white man's claim to connection with the land of the Natives is fictitious, fraudulent, and lacking in moral basis. Devilish schemes and bluffing are further elaborated throughout the lines. The oppressors take advantage of the Natives' goodness and naiveté. "Believing justice lived in the world," the Natives fall easy victims to the cunning of enemy. Over time however, the insidious plans are exposed when thieving starts; their horses, "so many, one by one stolen by the many thieves." Not taking only horses, the greedy settlers strip Indians of even of basic households and belongings, leaving them "longing for trees, for shade, homing, rooting, even more for food along the hunger way." Regardless, the brave Natives remain defiant. All acts of aggression have failed to break the pride of her nation or to put an end to the struggle "between the two worlds in this place." The injustices befalling her nation give rise to dreams and a will to resist the aggression and to keep struggling for the "things we were forced to leave behind, living country, stolen home." Furthermore, Hogan boldly warns the oppressor that the continuity of injustices might lead to "another red century," another bloody war, and, as a result, both will "end up crying together," as Trudell anticipates in his poem.

\subsection{Keesha M. Brown's Trails of Tears (2018)}

In Keesha M. Brown's Trails of Tears, history is also used as a source of empowerment rather than victimization. With no denial, the tragic events of the Trail of Tears "stifled" her nation but failed to "extinguish" the old flames of "the joyful peaceful years." The Natives still hold on to the old ways of traditional life. Their love and worship of the natural world, "sound and smell, and animal life," have ever remained deeply rooted, and have "survived the test of time," no matter the "deceptive lies" of the invaders. The atrocities and their devastating impact on the Natives are also elaborated. The Natives have suffered the worst, such as "death from exhaustion, sickness and disease, some from heartache," beside humiliating assimilation and relocation and withdrawal from sight or observation. Still they survive all forms of cruel atrocities and defy the circumstances. In the midst of afflictions, their faith in the world of spirits remains intact, providing souls with moral containment and empowerment: "they kept the Faith / the Creator consoled and strengthened / every step of the way." In the concluding lines, the poet redirects her discourse toward the Natives who are still living on the reservations. She warns "the descendants of those who didn't leave / continue on the native land" and that "The U.S. Feds can swoop in at any time / And take it back again." In a more confrontational tone than that of the other writers, Brown urges her people to stay united and be ready to do whatever it takes to resist trespassing. In a few words, Brown, as other poets, sees 
history as a motivation for her people to feel empowered to boldly confront any possible aggression.

\section{CONCLUSION}

In conclusion, the poems of the Trail of Tears still recount the Natives' holocaust and are motivation for their people to prove their resiliency and capacity to survive. The discourse of the nine selected poems is fashioned to lay their case before the world body of justice. They all make reference to all sorts of atrocities committed against a helpless nation: ethnic cleansing, genocides, indignation, and neglect. In addition, greed is named as the initiator of all evils and the chief motive of the Removal Act. They all warn that if greed is left unchecked, it will inevitably lead to the destruction of both the oppressed and oppressor. As well, all the verses illustrate an unshaken faith in the spirituality of nature and the immortality of souls, and make continuous reference to the spiritual natural world as an ally and source of empowerment and continuity. More importantly, through the arduous determination to protect the people's identity and sovereignty pressed in the poems, the poets aim to encourage the Natives to embrace their legitimate cause and continue to bravely resist the ongoing aggression against them. Five centuries of destruction have failed to erase, break, silence, or defeat the Natives. To the contrary, the sense of empowerment, felt throughout the verses and against all expectations, has grown deeper and fiercer regardless of time. All poets press the idea that their fate has not sealed yet. The industrious attempts of oppressors to erase their identity and force assimilation have failed thus far; and most importantly the Natives' continuity of resistance will eventually bear fruit.

\section{REFERENCES}

[1] Adams, Mattie Lorraine. (1973). Family Tree of Daniel and Rachel Davis. Duluth, Georgia, Claxton Printing Company.

[2] Archuleta, Elizabeth. (2006) “'I Give You Back': Indigenous Women Writing to Survive." Studies in American Indian Literatures, vol. 18, no. 4, pp. 88-114.

[3] Brown, Dee. (2007). Bury my Heart at Wounded Knee: An Indian History of the American West. New York, Macmillan,

[4] Brown, Keesha M. (2014). "Trails of Tears," https://www.firstpeople.us/native-american-poems/trails-oftears.html. Accessed 7 Sep 2019.

[5] Burnett, John G. (1890). "The Cherokee Removal Through the Eyes of a Private Soldier." https://www.warrenhills.org.domain/centricity/lib. Accessed on 15 Sep 2019
[6] Baird, David. (1973). The Choctaws Meet the Americans, 1783 to 1843. The Choctaw People. United States: Indian Tribal Series.

[7] Carter, Samuel. (1976). Cherokee Sunset: A Nation Betrayed: A Narrative of Travail and Triumph, Persecution and Exile. New York, Doubleday.

[8] Cave, Alfred A. (December 2003). "Abuse of Power: Andrew Jackson and The Indian Removal Act of 1830." Historian 66(6) 1330-1353.

[9] Childers, Brian. "The Trail of Tears" (1998). www.personal.kent.edu/ tweller2/Poetry - Part 1.html. Accessed on 24 Oct 2019.

[10] Gould, Janice. (1995) "American Indian Women's Poetry: Strategies of Rage and Hope." Signs 20, pp. 797-817.

[11] Grenke, Arthur. (2005). God, Greed, and Genocide: The Holocaust through the Centuries. Washington DC, New Academia Publishing, LLC,

[12] Hill, Sarah H. (2011). "To Overawe the Indians and Give Confidence to the Whites': Preparations for the Removal of the Cherokee Nation from Georgia." Georgia Historical Quarterly, vol. 95, no. 4, , pp. 465-497.

[13] Harjo, Joy, and et.al. ed. (1997) Reinventing the Enemy's Language: Contemporary Native Women's Writing of North America. New York, Norton and Company.

[14] Hernandez Avila, Ines (2002). It is What Keeps us Sisters: Indigenous Women and the Power of Story. Frontiers, vol. 23, no. 2, pp. ix- xviii.

[15] Hogan, Linda. (2014). "Trail of Tears: Our Removal," Dark Minneapolis, MN, Coffee House Press,

[16] Jones, Del Abe. "The Never-Ending Trail of Tears" (2005). http://www.personal.kent.edu/ tweller2/Poetry__Part_2.html. Accessed on 26 Sep 2019.

[17] Mojomike8. "The Trail of Tears Poem" (2012), https://www.warpaths2peacepipes.com/history-of-nativeamericans/trail-of-tears-poem.htm. 21 Sep 2019.

[18] Mooney, James. (2007). Myths of the Cherokee. New York, Barnes and Noble.

[19] Mooney, James. (2017). Historical Sketch of the Cherokee. New York: Routledge.

[20] Morris, Michael. (2007) "Georgia and the Conversation over Indian Removal." Georgia Historical Quarterly, vol. 91, no. 4, pp. 403-423

[21] Muskrat, Ruth Margaret. (1922). "Trail of Tears." University of Oklahoma Magazine, vol. 10, 1 Feb 1922, p. 14.

[22] Rader, Dean. (2002). "Word as Weapon: Visual Culture and Contemporary American Indian Poetry." Melus, vol. 27, no. 3 (Native American Literature), , pp. 147-167.

[23] Robertson, Debra. "A Trail of Tears" 2008, https://www.firstpeople.us/native-american-poems/trails-oftears.html. Accessed on 7 Sep, 2019. 
[24] Stannard, David E. (1993). American Holocaust: The Conquest of the New World, Oxford: Oxford University Press,

[25] Thornton, Russell. (1987). American Indian Holocaust and Survival: A Population History Since 1492. Oklahoma, University of Oklahoma Press.

[26] Trudell, John. (2008). "Cry Your Tears.” Lines from a Mined Mind. Golden, Colorado, Fulcrum Publishing.

[27] Ullman, Leslie. (1991). "Solitaries and Storytellers: Magicians and Pagans: Five Poems in the World." The Kenyon Review, vol. 13, no. 2, Spring, 1991, pp. 179-193.

[28] Wallace, Anthony. (2011). The Long, Bitter Trail: Andrew Jackson and the Indians. New York: Hill and Wang.

[29] Wood, Spiritwind. (2009). "And the Heavens Cried (Trail of Tears)", https://www.firstpeople.us/native-americanpoems/trails-of-tears.html. 7 Sep 2019. 